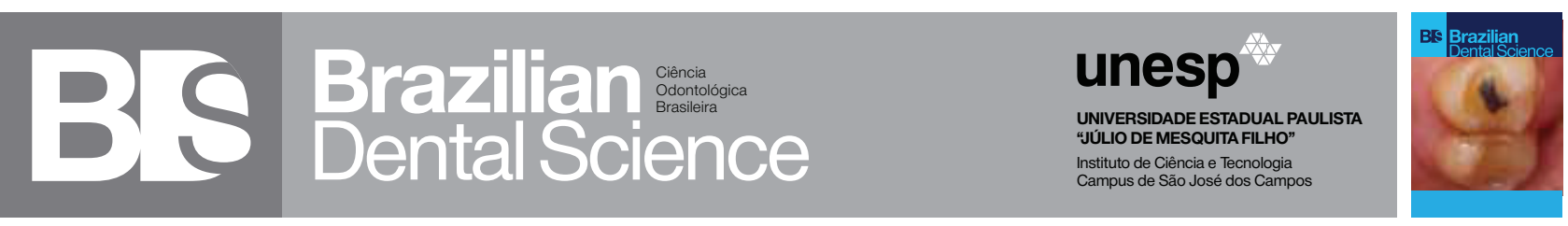

\title{
Dental erosion: an overview on definition, prevalence, diagnosis and therapy
}

Erosão dentária: uma visão sobre definição, prevalência, diagnóstico e terapia

Livia Picchi COMAR ${ }^{1}$, Priscila Maria Aranda SALOMÃO ${ }^{1}$, Beatriz Martines de SOUZA ${ }^{1}$, Ana Carolina MAGALHÃES

Department of Biological Sciences - Bauru School of Dentistry - University of São Paulo. Bauru, SP, Brazil.

\begin{abstract}
Currently, it has been observed a significant increase in the prevalence of dental erosion as a consequence of frequent exposure to acids from foods, drinks and gastric juice. The aim of this review was to give some new insights about the definition and diagnosis of this condition, to clarify the causal factors and to show the preventive strategies and restorative therapy. Dental erosion is complex condition dependent on the interaction of chemical, biological and behavior factors. The diagnosis is generally performed by the analysis of the clinical appearance of the lesions in combination with the patient's history. Some new technologies have been developed to help in early diagnosis and to quantify dental erosion in different phases. Preventive measures are established according to the causal factors, which may include the dietary intervention, modification of acidic drinks, and behavioral changes, or the modification of the tooth surface to increase its resistance against acidic attacks. The restorative treatment may range from minimally invasive therapies to multidisciplinary interventions. The clinicians should know how to detect the condition early, so that preventive measures can be applied before the lesions progress. Therapeutic strategies in high-risk patients should be as conservative as possible, involving multidisciplinary and preventive approaches with a periodic control for the success of the treatment.
\end{abstract}

\section{KEYWORDS}

Epidemiology; Prevention; Rehabilitation; Treatment; Tooth erosion.

\section{RESUMO}

Atualmente, tem-se observado um aumento significativo na prevalência de erosão dentária como consequência da exposição frequente aos ácidos oriundos de alimentos, bebidas e do suco gástrico. $\mathrm{O}$ objetivo desta revisão foi expor alguns novos direcionamentos sobre a definição e diagnóstico desta condição, esclarecer os fatores causais e apresentar as estratégias para a prevenção e o tratamento. A erosão dentária é uma condição complexa dependente da interação entre fatores químicos, biológicos e comportamentais. O diagnóstico é geralmente realizado por meio da análise da aparência clínica das lesões em combinação com a história do paciente. Novas tecnologias foram desenvolvidas para ajudar no diagnóstico precoce e para quantificar as diferentes fases da erosão dentária. As medidas preventivas são estabelecidas de acordo com os fatores causais que podem incluir a intervenção na dieta, modificação de bebidas ácidas, mudanças de comportamento, ou a modificação da superfície dentária com o objetivo de aumentar a sua resistência ao ataque ácido. O tratamento restaurador pode variar de terapias minimamente invasivas a intervenções multidisciplinares. Os clínicos devem saber como detectar a condição na sua fase inicial, para que medidas preventivas possam ser aplicadas antes da progressão da lesão. Estratégias terapêuticas em pacientes de alto risco devem ser as mais conservadoras possíveis, envolvendo abordagens multidisciplinares e preventivas com um controle periódico do paciente, para o sucesso do tratamento.

\section{PALAVRAS-CHAVE}

Epidemiologia; Prevenção; Reabilitação; Tratamento; Erosão dental. 


\section{INTRODUCTION}

$\mathrm{D}$ ental erosion is a tooth lesion caused by exposure to non-bacterial acids, which has been received attention from researchers and clinicians by its increasing prevalence and clinical detection [1,2]. Dental erosion presents two distinct phases recently classified as "Erosion" (Initial phase), in which there is a only softening of the tooth surface and "Erosive Tooth Wear" (Advanced Phase), with tooth surface loss due to the successive erosive attacks with a remained softened surface $[2,3]$. The remained softened layer presents low resistance to further erosive challenges as well as to mechanical wear by forces such as abrasion and attrition [4-6]. Attrition is defined as the wear of direct contact tooth-to-tooth, while abrasion occurs due to the presence of particles in movement and contact with the tooth surface as, for example, toothpaste and toothbrush [7]. Abfraction is a cervical lesion (shaped depressions) caused by flexural forces at the margin between enamel and cement, leading to enamel rods fracture [7]. When tooth lesion involves erosive and mechanical challenges is generally defined as "Tooth wear".

Dental erosion etiology is multifactorial involving chemical, biological and behavioral factors. These different factors help to explain the difference in erosion degree and susceptibility between people exposed to similar erosive environment [8]. Intrinsic and extrinsic acids are considered the main factors involved in the etiology of erosion [9]. The extrinsic acids are derived from the diet (acids from food and drinks) and occupation, such as frequent exposure to swimming pool chlorine and sulfuric acid gas from battery industries [10]. The erosive potential of drinks or acidic foods depends on chemical factors such as type of acid, $\mathrm{pH}$, titratable acidity, mineral content, viscosity, clearance and on calcium-chelation properties [8]. Extrinsic acids from the diet are becoming the most important source of erosive attacks due to increasing consumption of acidic drinks [10].

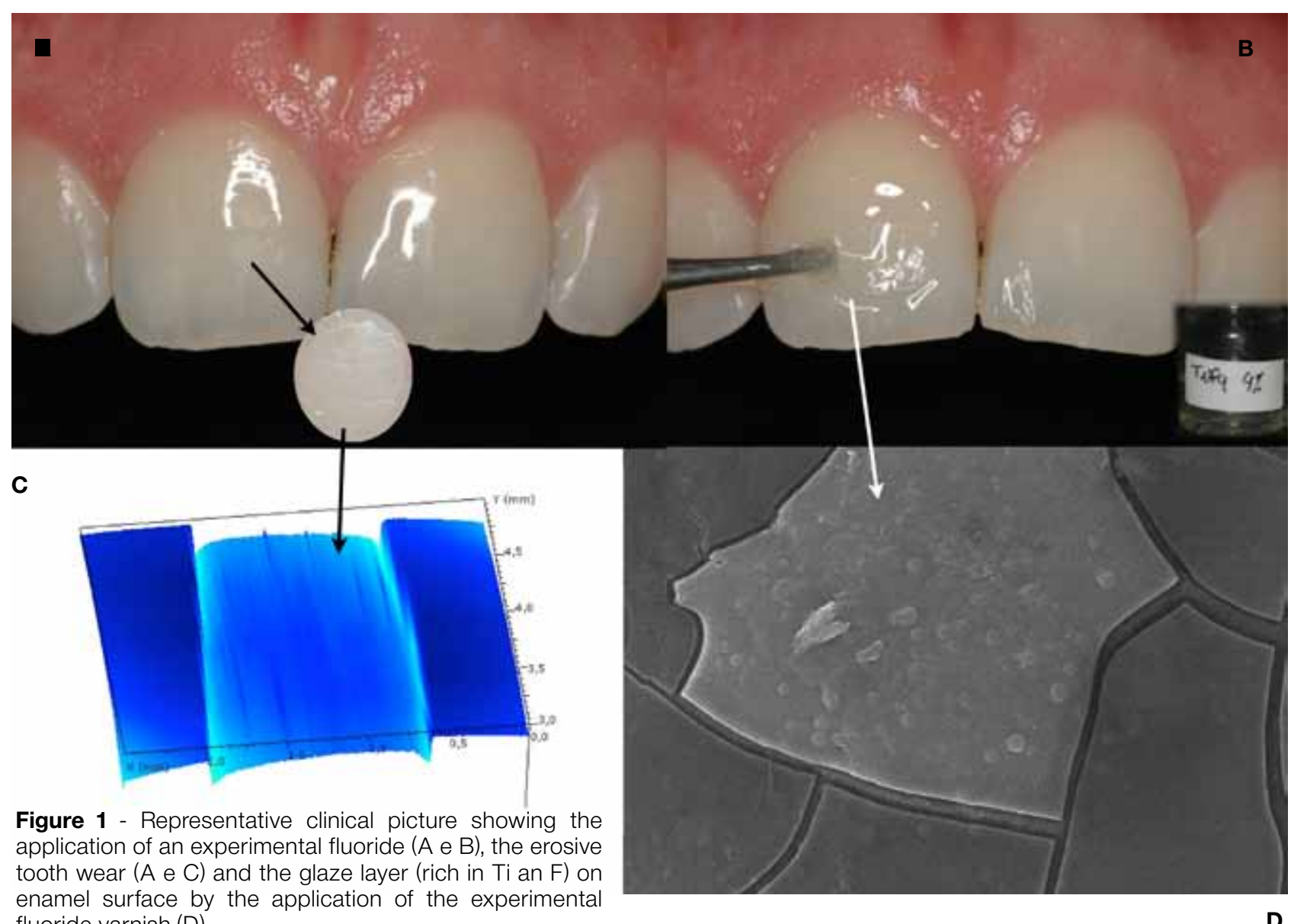
fluoride varnish (D) 
On the other hand, intrinsic acid is originated from the stomach in patients with regurgitation, reflux and psychosomatic disorders [11].

Salivary properties and tooth position as well mineralization take part of the biological factors. Low salivary flow and buffer capacity may be enrolled in high risk for erosion, $[12,13]$. Furthermore, the salivary pellicle formation has shown reduce the erosion development and progression [14-16], which has stimulated researchers to look for composition of salivary pellicle and the relationship with erosive susceptibility [17]. Finally, last but not least in importance, behavior factors include the frequency and the way that the patients are exposed to the different acids sources, bulimic practices and toothbrushing habits, such as time of brushing after meals, toothpaste's abrasivity and applied force $[8,18]$.

Nowadays, high prevalence of dental erosion, especially in children and adolescents, is being reported $[1,19]$. However, the prevalence of dental erosion varies significantly among the studies. Linnet \& Seow (2001) [20] showed that the prevalence of erosion in deciduous teeth was from 2 to 57\%. Kreulen et al. (2010) [1], in a recent systematic review, indicated that prevalence of wear involving dentin varied from 0 to $82 \%$ for deciduous teeth in children up to 7 years old, while in permanent dentition was from 0 to $54 \%$. In this study, deciduous tooth wear increased along to the age. According to Van't et al. (2009) [21] the level of tooth wear in adults is significantly associated with age, increasing from $3 \%$ at the age of 20 years to $17 \%$ at the age of 70 years. Nahás Pires Corrêa et al. (2011) [22] also found high prevalence of erosion linked with frequent soft drinks, sweets and fruits intake by children and adolescents.

Despite these studies, it is not clear if the prevalence of dental erosion is truly increasing or if only the increasing understanding about erosion has as consequence a more precise diagnosis. Therefore, the aim of this review was to give some new insights about the diagnosis of this condition, to clarify the causal factors and to show the preventive strategies and restorative therapy.

\section{DIAGNOSIS AND RISK FACTORS \\ Detection of erosive and/or tooth wear and assessment of the risk factors}

As previously mentioned dental erosion can be divided in two phases: initial phase denominated as "Erosion" (in which there is only softening) and the advanced phase denominated as "Erosive Tooth Wear" (with tooth surface loss) [2]. Dental erosion can be detected and quantity in both phases by using analytical methods in the laboratory; however, it can be only detected visually (or better clinically) in advanced phase.

A correct diagnosis of erosive or/and tooth wear (combination of different lesions) is essential for developing effective preventive and therapeutic strategies. Considering that erosion may be associated to other lesions, the first question that arises is: when dentist should consider erosive or/and tooth wear as pathological wear? In principle, abrasion and attrition may be considered as physiological wear along with the advance in age [23]. On the other hand, erosion involves acid attack, so it might be considered as pathological at all. In fact, there is no consensus about what it is physiological and pathological; but some points should be taken in mind during the wear diagnosis, to determine the needs of interventions: 1) age of the patient (age of the tooth); 2) the degree of wear (the severity); 3) and the presence of pain and the discoloration (the presence of pigmentation may mean that the lesion is old and not progressing).

The second question is: how to make the correct diagnosis? Clearly, the dentist should combine an adequate patient interview and a clinical examination. The dentist should ask questions that may be involved in the etiology of erosive/ tooth wear, such as: general health, medicine intake (vitamin $\mathrm{C}$, aspirin and anticholinergic drugs, the last medication is involved in salivary flow decrease), drugs (ecstasy), past and present acidic diet (soft drink, citric fruits, alcoholic drink, vinegar), environmental acids exposure (occupational information), the presence of gastro-esophageal reflux disease, vomiting or bulimia/anorexia, toothbrushing habit and bruxism. Assessment of saliva flow rates and buffer capacity, whenever possible, may help in the diagnosis.

From the interview, the dentist can determine the risk factors. Lussi \& Schaffner (2000) [24] showed that four or more dietary acid intakes per day, a low buffering capacity of stimulated saliva and the use of hard bristle toothbrush are associated with high risk for 
tooth wear. Intake frequency and some habits such as swishing, sucking or holding drink in the mouth are also risk factors for erosive wear $[12,22,25,26]$. The gastro-esophageal reflux is another important factor associated to increasing risk for erosion $[25,26]$.

As part of the diagnosis process, an appropriate clinical examination of cleaned and dried teeth using an artificial light is the most important tool to really detect the condition. Accordingly, the major concerns in the clinical diagnosis are: 1) the detection of early stage (involving enamel only), in which there are few signs and no symptoms; and 2) to differentiate "pure" erosive wear from tooth wear.

The most susceptible surfaces for erosion are labial and palatal aspects of all upper teeth (especially anterior teeth) and occlusal surfaces of the lower first molars. For facial/lingual surfaces, the signs include: the appearance of smooth silky-glazed, sometimes dull (in case of progressive tooth loss), the absence of perikymata and the presence of intact enamel along the gingival margin, which is protected from the acid by the biofilm and/or gingival fluid [8]. As enamel becomes thinner, yellow dentin appears. In advanced phase, concavities wider than deeper and fractures of the incisal borders can be seen. In this stage, patients complain of poor aesthetics and pain.

Facial erosion should be distinguished from wedge-shaped defects (Abfraction), which are located apically to the enamel-cementum junction. The coronal part of wedge-shaped defects has a sharp margin and cuts at right angle into the enamel surface. Besides, the abfraction lesion is deeper than wider and often involves one tooth, e.g. superior pre-molar $[8,27]$.

When erosion is mainly localized on facial surfaces, extrinsic acids may be involved in its development. However, when lingual surfaces are most involved, the intrinsic acids probably are the main cause for the condition. Other important point is that abrasion may also occur on facial surface. Generally, abrasive forces lead to gingival recession and the wear is more localized on cervical areas, showing lines corresponding to the brushing bristles. Besides, abrasion is localized on prominent superior teeth (e.g. canines and pre-molars).

In respect to the occlusal/incisal lesions, the first signals are similar to the facial/lingual ones. However, in the advanced phases, there is a formation of small cups and the restorations rise above of the level of the tooth surface. In severe cases, the whole occlusal morphology may be rubbed off $[8,27]$. To distingue erosion from attrition, one important clinical feature is that attrition involves a flat and gloss area, which corresponds to the contact with antagonist teeth.

It is important to differentiate the type of lesion for better determining the preventive and restorative strategies. However, the differential diagnosis is a challenge once different lesions may occur simultaneously on the same tooth surface. Then, the dentist must use the interview to determine which lesion (erosion, abrasion, attrition or abfraction) is more prevalent.

Other important clinical point discussed by Wang \& Lussi (2010) [27] is wherever patients with erosion may present caries lesions. Evidently, tooth surfaces with active erosion (painful and unstained surface) have no caries lesions. However, caries lesions may occur in patients with erosion at other sites with biofilm accumulation.

The third question addressed is: how to monitor the activity and progression of erosive and/or tooth wear? In the sequence of this text, some clinical and complementary approaches will be presented together with the advantages and limitations of each method.

\section{CLINICAL INDICES}

Several indices have been developed for epidemiological and clinical purposes. Most indices consider the presence or absence of dentin exposure as clinical criteria to determine erosion severity. The scoring systems mainly differ among them in clinical criteria, scale and chosen teeth.

The first developed index classifies the lesions of four anterior teeth surfaces only in early, small and advanced. This index was created by Eccles (1978) [28] and improved one year later [29]. Thereafter, Smith \& Knight (1984) [30], based on Eccles ' index, created the tooth wear index (TWI). TWI consists in evaluating the surfaces of all teeth (buccal, cervical, lingual and occlusal/incisal surfaces) and classifies them using 5 scores: 0 - no wear; 1- enamel wear; 2 - dentin exposed for less than 
$1 / 3$ of surface; 3 - more than $1 / 3$ of dentin exposed; 4- pulp exposure or secondary dentin.

Millward et al. (1994) [31] modified the TWI to study erosive wear in young (primary and permanent teeth). This index excludes cervical surfaces and includes score 9 corresponding to excluded tooth. Two years later, Lussi (1996) [32] created another index to classify erosive wear of facial (4 scores) and occlusal/ lingual (3 scores) surfaces from all teeth. In 2000, O'Sullivan [33] worked with an index, which measures: the degree of wear in 7 levels (including score 9- excluded tooth), the affected surface (single or multiple surfaces) and the area of the affected surface (less or more than half surface). All these indices have been applied in epidemiological studies.

Recently, a scoring system termed the basic erosive wear examination (BEWE) was developed for use in general practice and to allow comparison with other indices [34]. This new index was created to overcome some limitations of the past indices, reducing the overestimation of the prevalence, improving early detection and finally, linking the detection and severity with the therapy. Each sextant is scored independently, as follows: 0- no wear; 1 - initial loss of surface texture; 2 - distinct defect, hard tissue loss $<50 \%$ of the surface area (dentin involved in most cases); 3 - hard tissue loss $>50 \%$ of the surface area (dentin involved in most cases). The highest score found for each sextant (the tooth that presents the worst case) is summed and the final number determines the therapies, according to the severity level: $<2$ none, 3-8 low, 9-13 medium and $>14$ high. The researchers expect that this index will be adopted internationally to standardize the measurement of erosive wear and the comparison among the epidemiological studies.

Despite the researchers have hardly worked in improving the indices, there is a need of testing the validity, sensibility, specificity and reliability of the indices in erosion diagnosis for research and clinical purposes [23]. Furthermore, the indices must be applied together with the patient interview and the risk assessment, allowing that a more accurate diagnosis of the condition can be achieved [35].

Considering that surface loss, in most cases, progresses slowly, the clinical indices applied in diagnosis are still not enough sensitive to monitor the progression of erosive wear overtime. Therefore, the dentist can use complementary methods to help in the control of the erosion progression by comparing clinical photographs of the tooth surfaces, study casts and dental radiography (bitewings may show molar mesialization due to occlusal wear) [8].

\section{COMPLEMENTARY METHODS}

\section{a. Initial phase (Erosion)}

Nowadays, other techniques, involving optical properties changes in tooth, are being applied to detect erosive surface demineralization (first phase) [36]. Currently, the two most promising methods for assessing enamel in vivo are quantitative light-induced fluorescence (QLF) and optical coherence tomography (OCT) [2]. For QLF, an area with little or no surface scattering needs to be analyzed as a reference area to calculate relative loss of fluorescence in the demineralized area. This is useful for experimental clinical studies, but not to be applied in diagnosis by clinicians, considering that a reference surface might be not available in the patient with severe case of erosion. Furthermore, there are few studies in this subject [37-39] and the cost-benefit has been discussed. Therefore, QLF should be validated before being applied in erosion assessment.

OCT for erosion is based upon quantitative measurements of the backscattered light intensity at the surface, which indicates surface porosity and also penetration depth of the region of interest, which is reduced when surface scattering occurs. As for QLF, the eroded area should be compared to a reference area, and this is again a limitation for clinical detection. Furthermore, these techniques are applicable to smooth surfaces and not to occlusal ones. Other weak point is that, ideally, accurate repositioning of the probe is required, so that the same area can be measured at different time points to monitor the condition.

Therefore, further studies are required to check if both technics are valid for erosion detection [38]. Several other parameters that may influence the analysis of optical properties changes, such as the presence of an acquired salivary pellicle, teeth abrasion, hydration degree and native tooth color, should be considered in further studies [36]. 


\section{b. Advanced phase (Erosive wear)}

Other approach is the use of the indirect profilometry that is indicated for the longitudinal monitoring of erosive wear in clinical research. Firstly, metal marker must be bonded onto the palatal surfaces of upper incisors as a reference point. Thereafter, impressions and/or study casts are obtained at baseline and at different follow-up intervals, and subjected to scanning using profilometer $[40,41]$. The differences in height between the metal (acid resistant) and tooth surface are calculated, for monitoring the progression of tooth wear over the followup period. However, there are some limitations of the method such as cost, and the need to attach and to keep the metal marker overtime. Furthermore, the metal marker must be not damage, so an adequate interoclusal space is required. Likewise the contact profilometer, other approaches are null-contact profiler and optical 3D sensor [42,43]. However, more studies are needed to check the sensitivity and validity of these methods.

\section{WEAK POINT IN DIAGNOSIS}

The differential diagnosis of erosive and tooth wear, especially at the first stages (enamel wear), is not easy to make. Nevertheless, more complicate than the early detection is the monitoring of the lesions overtime. The follow-up is particularly important to determine the progression rate of the wear in physiological and pathological cases. There are few reports about physiological and pathological wear progression. Generally, the studies have shown that the progression varied from 3.7 to 29 and from 35 to $350 \mu \mathrm{m}$ per year for physiological and pathological wear, respectively [2,11,38,44-46].

Therefore, clinical and complementary methods must be developed, improved and validated, together with the risk assessment, to evaluate erosion and erosive and/or tooth wear in vivo, and to better plan the preventive and therapeutic strategies.

\section{PREVENTIVE STRATEGIES}

Preventive measures for dental erosion, including chemical, biological and behavior factors, should be specific for each patient [27]. Clearly, a reduction in acid exposure is the most effective and universal preventive strategy to be applied in high-risk patients. The consumption of potentially erosive foods and beverages should be limited to main meals only [27]. Some habits, like drinking and holding in the mouth as well as nipping from a bottle should be avoided, because prolong contact time of acid with the tooth increases the susceptibility to erosion $[8,22,25,27]$.

As oral hygiene measures may be involved in tooth wear, the time point of toothbrushing after an erosive attack as well as the applied force and type of toothpaste used must be controlled [8]. Despite no scientific evidence exists about the time point of toothbrushing; it is advised to wait $30 \mathrm{~min}$ to $1 \mathrm{~h}$ to brush after meals for highrisk patient $[4,6,27]$. The toothpaste abrasivity is correlated with type, quantity and size of the abrasive, the fluoride concentration and $\mathrm{pH}$ as well [47]. Nevertheless, the dentists do not know the exact toothpaste abrasivity, so no trustful instruction can be given about this issue.

Personal protective equipment (respiratory masks) and adherence to threshold limit values recommended by occupational health legislations are considered an important preventive strategy to decrease occupational erosion [48]. Within behavior factors, erosive tooth wear is a common manifestation in patients suffering from organic or psychosomatic disorders such as gastro-esophageal reflux disease (GERD), anorexia or bulimia nervosa or alcohol abuse. These disorders require a multidisciplinary therapy, including general medicine and psychological treatment, for decrease the intrinsic acid exposure [49].

Studies have also shown that erosion may be associated with biological factors such as low salivary buffering capacity and flow $[12,24]$. Changes in saliva may be caused by head and neck radiation, use of some medications, as well as GERD [50,51]. Considering that saliva has important functions (buffer capacity and remineralizing effect), salivary stimulation through the use of chewing gum [6] and consumption of cheese or milk after meal [52] can help to reduce the erosion progression. Saliva is also able to promote the acquired pellicle formation. The pellicle is a diffusion barrier that reduces the contact between the acid and the tooth surface [14-16]. Recent researches are focus on the formation, ultrastructure, composition and functions of the acquired pellicle $[53,54]$. 
Nowadays, the modification of the tooth surface to increase the resistance against acidic attacks is the most useful strategy studied so far. One approach to increase the tooth resistance is by the fluoride application [55,56]. Topical fluoridation induces the formation of a protective layer on dental hard tissue, which is composed of $\mathrm{CaF}_{2}$ (in case of conventional fluorides like amine fluoride or sodium fluoride) $[56,57]$ or of metal-rich surface precipitates (in case of titanium tetrafluoride or tin-containing fluoride products) [56,58,59].

There is convincing evidence that fluoride, in general, can strengthen tooth against erosive acid damage. High concentration fluoride agents and/or frequent applications are considered potentially effective approaches to reduce erosive tooth wear in vitro and in situ. Conventional fluoride has limited effect against dental erosion $[58,60]$. Then, the use of tincontaining fluoride products, such as mouthrinse and toothpaste, might provide the best approach for effective prevention of dental erosion [61-63]. Titanium tetrafluoride seems to be promising agent, especially when added into a varnish $[58,64]$. However, the efficacy of $\mathrm{TiF}_{4}$ is highly dependent on its low $\mathrm{pH}[65,66]$, which implicates in special care during the application, not allowing self-application by the patient. Further clinical studies are recommended to better understand the relative differences in performance of the various fluoride agents and to allow the correct prescription in the clinic.

Recently, new products (especial toothpastes) with anti-erosive ingredients were developed and some included in the market, but few are known about their effectiveness. The possible anti-erosive toothpastes are those containing $\mathrm{KNO}_{3}$ (anti-hypersensitivity agent), hydroxyapatite (HA) with or without F, Zncarbonate HA, calcium sodium phosphosilicate (remineralizing agents) and chitosan (act as pellicle) [63,67,68]. Additionally, potential MMPs inhibitor as chlorhexidine and green tea extract has been tested against dentin erosion progression with promising results [6971]. However, further studies should confirm the results obtained to give support for the establishment of clinical protocols.

The modification of beverage or food is other preventive strategy, related to chemical factor, which is less dependent on the patient's behavior. The reduction of the erosive potential of acidic beverages can be achieved by adding ions (calcium, phosphate and fluoride) that make the beverage more saturated in respect to HA [72,73] or polymers (pectin, alginate and gum arabic polymers), which adsorb the enamel surface, protecting it mechanically $[74,75]$. The addition of calcium or polymer has been shown to reduce the erosive potential of pure acids and acidic drinks [72-75]. However, future studies should give special emphasis on the consequences of the modification regarding taste, stability of the solution and systemic effects for the patients.

Since preventive strategies may fail and dentist may not detect dental erosion early, new insights into therapy strategies are necessary. Therefore, the last part of this review is focus on the possibilities and outcome of restorative treatment.

\section{Therapeutic approach}

The restorative treatment is indicated when the tooth integrity is threatened, the esthetics is impaired, or there is dentinal hypersensitivity and the pulpal exposure is likely to occur [27]. The first step of the treatment is based on the elimination or control of the causal agents for preventing the progression of wear [44].

According to Johansson et al. (2008) [76], it is recommended that serial observations be performed using study casts or photographs at approximately 6-12 months intervals. Based on the assessment of progression rate of the wear and the symptoms, it is possible to decide whether intervention is necessary or not. However, in cases in which an active erosive influence has been installed, some procedures should be carried out as soon as possible.

Currently, there are several options for the treatment of tooth wear, which can range from a conservative (adhesive and composite resins restorations) to more invasive procedures (crows, bridges or even full-mouth reconstruction) in cases of severe tooth wear $[27,77]$.

For primary and mixed dentition, in which the child does not present any symptom, restorative treatment usually is not indicated. In this case, the follow-up is particularly important to control the etiological factors that may implicate in high risk for erosion in permanent 
teeth [78]. However, if teeth are sensitive, small areas of erosion can be covered with composite resin and larger areas may require composite crows on anterior teeth and preformed metal crows on posterior teeth [78]. For severe symptoms, extraction may be indicate depending on the tooth`s age.

Different from dental caries, tooth wear generally involves several teeth. Therefore, the rehabilitation is more complex and expensive, involving multidisciplinary approaches (operative dentistry, prosthesis, orthodontic, implants, periodontology and endodontic).

In case of localized and shallow wear in permanent tooth, without symptoms and progression, the dentist can only monitor without the need to repair the tooth. Other option in this case is the application of adhesive agents, which may be effective in reducing sensitivity and preventing further wear for approximately 3-6 months [79-81].

When restorative treatment is required, it is important to choose a material resistant to erosion and that allows the preservation of the tooth as much as possible [82]. Accordingly, glass ionomer cements seem not to be the best option, as they are susceptible to acid dissolution [83]. Honório et al. (2008) [84] demonstrated that the glass ionomer cements exhibited higher hardness loss and wear compared to a composite resin and amalgam, after 35 days of erosive challenges in vitro. The application of a composite resin has the advantage of providing good longevity and aesthetic. Additionally, it has shown success in the rehabilitation of eroded dentitions $[81,85]$, reducing the sensitivity and improving the appearance.

In the sequence of this text, the treatments for permanent teeth are described according to the area and degree of severity.

\section{Anterior teeth}

Buccal and palatal surfaces can be mostly restored with composites or combination of composite resin and glass ionomer cement; the last option is applicable for deep tooth wear and cervical lesions. In aggressive cases, veneers or ceramic/ metal-ceramic crows are options for rehabilitation [78]. Endodontic treatment is the last choice for extreme dentin hypersensitivity, which cannot be treated more conservatively, or when periodontal surgery is required [76].
When the wear involves palatal and incisal surfaces, the assessment of the space in the intercuspal position (ICP) is indispensable for a correct rehabilitation [78]. Extensive wear may result in changes in the occlusal vertical dimension (OVD) [76]. In case of severe wear involving anterior and posterior teeth, multidisciplinary approach should be studied [76].

The OVD can be increased by orthodontic treatment, using fixed or removable appliances, such as the Dahl appliance. This management may avoid the need of additional tooth wear [86]. The Dahl appliance allows relative extrusion of posterior teeth and intrusion of anterior teeth, in order to gain space for the restoration of eroded upper anterior teeth [78]. Thereafter, the eroded tooth can be reconstructed [85]. Other treatment option for mild cases of OVD loss is the placement of veneer on lingual surface that can allow the extrusion of posterior teeth in some extent.

In a clinical study, Hemmings et al. (2000) [87] restored localized anterior tooth wear with direct composite restorations in patients with loss of interocclusal space, increasing the OVD. The restorations were placed to increase the OVD, creating a posterior disclusion of 1 to 4 $\mathrm{mm}$. After follow-up of 30 months, the authors observed success with $89 \%$ of the restorations in place. Furthermore, the patient satisfaction was reported as good.

Other possibilities for obtaining space for the rehabilitation are the use of temporary crown and the combination of tooth preparation/wear and periodontal surgery. In the last case, some conditions should de analyzed as bone quantity and quality, size of the root and the smile line in case of anterior teeth.

\section{POSTERIOR TEETH AND GENERALIZED WEAR}

Tooth wear involving only posterior teeth is an unusual condition. When tooth wear is localized in posterior tooth, composite restorations and crowns are able to restore the condition depending on the severity [78]. However, generalized erosion wear may result in mandibular over-closure, in which compensatory over-eruption is likely to maintain the existing OVD [78]. In some cases, it is necessary to increase the OVD, where interocclusal space is critical for rehabilitation [76]. 
According to Jaeggi et al. (2006) [88], for the OVD loss lesser than $0.5 \mathrm{~mm}$, sealing or restorations with composite resin are indicated. In case of loss between 0.5 and $2.0 \mathrm{~mm}$, the teeth can be reconstructed with composite resin, because the patient can tolerate this small increase in OVD. When the posterior tooth wear is localized and not severe, an option to allow the tooth rehabilitation without the need of increase the OVD is the periodontal surgery. A careful analysis of the root and bone conditions should be done prior the surgery. For loss between 2.0 and $4.0 \mathrm{~mm}$, indirect porcelain veneers or provisory crowns may be used for the treatment. In case of severe tooth wear, metal-ceramic crowns are more appropriate. In case of OVD loss higher than $4.0 \mathrm{~mm}$, the recovery must be performed using alternative techniques as orthodontic appliances and mini-implants [76]. Table 1 shows the most useful options for tooth rehabilitation according to the worn area and the degree of severity. In this Table, the guide for clinical management according to the BEWE risk level is also available.

In cases of full-mouth rehabilitation, the preparation of multiple teeth for conventional crowns or the placement of implants requires great care, especially in case in that some preserved natural teeth are in occlusal contact with crowns or partial denture $[76,89]$

\section{Follow-up}

Regular follow-up is critical for the treatment success. Cases should be reviewed at least annually when new study casts and photographs should be taken. Furthermore, preventive regimens should be often revised. The determination of the interval between the visits should be based on the risk assessment as stated in the BEWE index (Table 1).

\section{CONCLUSION}

As there are signs that the prevalence of erosion is increasing in several countries, the dentist should have knowledge about its etiology and be prepared for early diagnose. Therefore, future researches should give advances in early diagnosis, so that preventive measures can be applied appropriately. When dental erosion involves dentin with pain, function and aesthetic limitation, rehabilitation is required. Therapeutic strategies in high-risk patients should be as conservative as possible, involving multidisciplinary and preventive approaches with a periodic control for the treatment success.

Table 1- Guide for clinical management according to Jaeggi et al. (2006) [88] and BEWE [34]

\begin{tabular}{|c|c|c|c|c|c|}
\hline Area & $\begin{array}{l}\text { Enamel } \\
(0.5-2 \mathrm{~mm})\end{array}$ & $\begin{array}{l}\text { Shallow dentin } \\
(2-4 \mathrm{~mm})\end{array}$ & $\begin{array}{l}\text { Deep dentin } \\
\text { (»4 mm) }\end{array}$ & $\begin{array}{c}\text { Cumulative } \\
\text { score (BEWE)* }\end{array}$ & Management \\
\hline $\begin{array}{l}\text { Anterior } \\
\text { (one face) }\end{array}$ & $\begin{array}{c}\text { Monitoring } \\
\text { Application of adhesive } \\
\text { or fluid resin }\end{array}$ & $\begin{array}{l}\text { Restoration with com- } \\
\text { posite resin }\end{array}$ & $\begin{array}{c}\text { Restoration with } \\
\text { composite resin and } \\
\text { glass ionomer cement } \\
\text { or veneer }\end{array}$ & $3-8$ & $\begin{array}{l}\text { Identify the causal factors; } \\
\text { advice about oral hygiene } \\
\text { and diet; follow-up intervals } \\
\text { of } 1-2 \text { years }\end{array}$ \\
\hline $\begin{array}{l}\text { Anterior (several } \\
\text { faces) }\end{array}$ & $\begin{array}{c}\text { Monitoring } \\
\text { Application of adhesive } \\
\text { or fluid resin }\end{array}$ & $\begin{array}{l}\text { Restoration with } \\
\text { composite resin with or } \\
\text { without glass ionomer } \\
\text { cement or crowns }\end{array}$ & $\begin{array}{l}\text { Metal-ceramic or } \\
\text { ceramic crowns }^{\star \star}\end{array}$ & $9-13$ & $\begin{array}{l}\text { The same as above plus } \\
\text { fluoride application; avoid } \\
\text { restorations; monitoring } \\
\text { each 6-12 months }\end{array}$ \\
\hline Posterior & $\begin{array}{l}\text { Monitoring } \\
\text { Application of adhesive } \\
\text { or fluid resin }\end{array}$ & $\begin{array}{c}\text { Restoration with } \\
\text { composite resin with or } \\
\text { without ionomer cement } \\
\text { or crowns }\end{array}$ & $\begin{array}{l}\text { OVD recovery with } \\
\text { orthodontic or surgery; } \\
\text { metal-ceramic crowns }\end{array}$ & »4 & $\begin{array}{l}\text { The same as above plus } \\
\text { restorative treatments } \\
\text { (severe lesions); follow-up } \\
\text { at each } 6 \text { months. }\end{array}$ \\
\hline
\end{tabular}

${ }^{*}$ BEWE score « 2 : follow-up at 3 years intervals; ${ }^{\star \star}$ OVD recovery may be necessary in case of generalized tooth wear. 


\section{REFERENCES}

1. Kreulen CM, Van 't Spijker A, Rodriguez JM, Bronkhorst EM, Creugers $\mathrm{NH}$, Bartlett DW. Systematic review of the prevalence of tooth wear in children and adolescents. Caries Res. 2010;44(2):151-9.

2. Huysmans MC, Chew HP, Ellwood RP. Clinical studies of dental erosion and erosive wear. Caries Res. 2011;45(Suppl 1):60-8.

3. Shellis RP, Ganss C, Ren Y, Zero DT, Lussi A. Methodology and models in erosion research: discussion and conclusions. Caries Res. 2011;45(Suppl 1):69-77.

4. Attin T, Knöfel S, Buchalla W, Tutuncu R. In situ evaluation of different remineralization periods to decrease brushing abrasion of demineralized enamel. Caries Res. 2001 May-Jun;35(3):216-22.

5. Addy M, Hunter ML. Can tooth brushing damage your health? Effects on oral and dental tissues. Int Dent J. 2003;53(Suppl 3):177-86.

6. Rios D, Honório HM, Magalhães AC, Delbem AC, Machado MA, Silva $\mathrm{SM}$, et al. Effect of salivary stimulation on erosion of human and bovine enamel subjected or not to subsequent abrasion: an in situ/ ex vivo study. Caries Res. 2006;40(3):218-23.

7. Imfeld T. Dental erosion. Definition, classification and links. Eur J Oral Sci. 1996 Apr;104(2):151-5.

8. Lussi A, Jaeggi T. Erosion diagnosis and risk factors. Clin Oral Investig. 2008 Mar;12(Suppl 1):S5-13.

9. Lussi A, Jaeggi T. Chemical factors. Monogr Oral Sci. 2006;20:77-87.

10. Lussi A. Erosive tooth wear - a multifactorial condition of growing concern and increasing knowledge. Monogr Oral Sci. 2006;20:1-8.

11. Bartlett D. Intrinsic causes of erosion. Monogr Oral Sci. 2006;20:11939.

12. O'Sullivan EA, Curzon MEJ. A comparison of acidic dietary factors in children with and without dental erosion. J Dent Child. 2000;78:18692.

13. Jensdottir T, Buchwald C, Nauntofte B, Hansen HS, Bardow A. Saliva in relation to dental erosion before and after radiotherapy. Acta Odontol Scand. 2012 Nov 21. [Epub ahead of print].

14. Hannig M, Fiebiger M, Güntzer M, Döbert A, ZimehI R, Nekrashevych Y. Protective effect of the in situ formed short-term salivary pellicle. Arch Oral Biol. 2004 Nov;49(11):903-10.

15. Hara AT, Ando M, Gonzãlez-Cabezas C, Cury JA, Serra MC, Zero DT. Protective effect of the dental pellicle against erosive challenges in situ. J Dent Res. 2006 Jul;85(7):612-6.

16. Buzalaf MA, Hannas AR, Kato MT. Saliva and dental erosion. J Appl Oral Sci. 2012 Sep-0ct;20(5):493-502.

17. Cheaib Z, Lussi A. Impact of acquired enamel pellicle modification on initial dental erosion. Caries Res. 2011:45(2):107-12.

18. El Aidi H, Bronkhorst EM, Huysmans MC, Truin GJ. Multifactorial analysis of factors associated with the incidence and progression of erosive tooth wear. Caries Res. 2011;45(3):303-12.

19. Jaeggi T, Lussi A. Prevalence, incidence and distribution of erosion. Monogr Oral Sci. 2006;20:44-65.

20. Linnett V, Seow WK. Dental erosion in children: a literature review. Pediatr Dent. 2001 Jan-Feb;23(1):37-43

21. Van't Spijker A, Rodriguez JM, Kreulen CM, Bronkhorst EM, Bartlett DW, Creugers NH. Prevalence of tooth wear in adults. Int J Prosthodont. 2009 Jan-Feb;22(1):35-42
22. Nahás Pires Corrêa MS, Nahás Pires Corrêa F, Nahás Pires Corrêa JP, Murakami C, Mendes FM. Prevalence and associated factors of dental erosion in children and adolescents of a private dental practice. Int J Paediatr Dent. 2011;21(6):451-8.

23. Young A, Amaechi BT, Dugmore C, Holbrook P, Nunn J, Schiffner U, et al. Current erosion indices--flawed or valid? Summary. Clin Oral Investig. 2008;12 Suppl 1:S59-63.

24. Lussi A, Schaffner M. Progression of and risk factors for dental erosion and wedge-shaped defects over a 6-year period. Caries Res. 2000;34:182-7.

25. Rios D, Magalhães AC, Honório HM, Buzalaf MA, Lauris JR, Machado $M A$. The prevalence of deciduous tooth wear in six-year-old children and its relationship with potential explanatory factors. Oral Health Prev Dent. 2007:5(3):167-71.

26. Murakami C, Oliveira LB, Sheiham A, Nahás Pires Corrêa MS, Haddad $\mathrm{AE}$, Bönecker M. Risk indicators for erosive tooth wear in Brazilian preschool children. Caries Res. 2011;45(2):121-9.

27. Wang $X$, Lussi A. Assessment and management of dental erosion. Dent Clin North Am. 2010;54(3):565-78.

28. Eccles JD. The treatment of dental erosion. J Dent. 1978;6:217-21

29. Eccles JD. Dental erosion of nonindustrial origin. A clinical survey and classification. J Prosthet Dent. 1979;42:649-53.

30. Smith BG, Knight JK. An index for measuring the wear of teeth. Br Dent J. 1984;156:435-8.

31. Millward A, Shaw L, Smith AJ, Rippin JW, Harrington E. The distribution and severity of tooth wear and the relationship between erosion and dietary constituents in a group of children. Int J Paediatr Dent. 1994:4:151-7.

32. Lussi A. Dental erosion clinical diagnosis and case history taking Eur J Oral Sci. 1996 Apr;104(2 Pt 2):191-8.

33. OSullivan EA. A new index for the measurement of erosion in children. Eur J Paediatr Dent. 2000;1:69-74.

34. Bartlett D, Ganss C, Lussi A. Basic erosive wear examination (BEWE): a new scoring system for scientific and clinical needs. Clin Oral Investig. 2008:12(suppl 1):S65-8.

35. Margaritis V, Mamai-Homata E, Koletsi-Kounari H, Polychronopoulou A. Evaluation of three different scoring systems for dental erosion: a comparative study in adolescents. J Dent. 2011;39(1):88-93.

36. Rakhmatullina E, Bossen A, Höschele C, Wang X, Beyeler B, Meier $C$, et al. Application of the specular and diffuse reflection analysis for in vitro diagnostics of dental erosion: correlation with enamel softening, roughness, and calcium release. J Biomed 0pt. 2011;16(10):107002.

37. Pretty IA, Edgar WM, Higham SM. The validation of quantitative light-induced fluorescence to quantify acid erosion of human enamel. Arch Oral Biol. 2004;49:285-94.

38. Wilder-Smith $\mathrm{CH}$, Wilder-Smith $\mathrm{P}$, Kawakami-Wong $\mathrm{H}$, Voronets $\mathrm{J}$ Osann K, Lussi A. Quantification of dental erosions in patients with GERD using optical coherence tomography before and after doubleblind, randomised treatment with esomeprazole or placebo. Am J Gastroenterol. 2009;104:2788-95.

39. Elton V, Cooper L, Higham SM, Pender N. Validation of enamel erosion in vitro. J Dent. 2009;37:336-41. 
40. Bartlett DW, Evans DF, Anggiansah A, Smith BG. A study of the association between gastro-oesophageal reflux and palatal dental erosion. Br Dent J. 1996;181:125-31.

41. Schlueter N, Ganss C, De Sanctis S, Klimek J. Evaluation of a profilometrical method for monitoring erosive tooth wear. Eur J Oral Sci. 2005;113:505-11.

42. Mehl A, Gloger W, Kunzelmann KH, Hickel R. A new optical 3-D device for the detection of wear. J Dent Res. 1997;76:1799-807.

43. Pesun IJ, Olson AK, Hodges JS, Anderson GC. In vivo evaluation of the surface of posterior resin composite restorations: a pilot study. J Prosthet Dent. 2000;84:353-9.

44. Lambrechts P, Van Meerbeek B, Perdigão J, Gladys S, Braem M, Vanherle G. Restorative therapy for erosive lesions. Eur J Oral Sci. 1996 Apr;104(2 Pt 2):229-40.

45. Pintado MR, Anderson GC, DeLong R, Douglas WH. Variation in tooth wear in young adults over a two-year period. J Prosthet Dent. 1997;77:313-20.

46. Sundaram G, Wilson R, Watson TF, Bartlett D. Clinical measurement of palatal tooth wear following coating by a resin sealing system. Oper Dent. 2007;32:539-43.

47. Moron BM, Satie S, Ito N, Wiegand A, Vilhena F, Buzalaf MAR, et al. Impact of different fluoride concentrations and $\mathrm{pH}$ of dentifrices on tooth erosion/abrasion in vitro. Aust Dent J. 2013;58:1-6.

48. Wiegand A, Attin T. Occupational dental erosion from exposure to acids: a review. Occup Med (Lond). 2007 May;57(3):169-76.

49. Ranjitkar S, Kaidonis JA, Smales RJ. Gastroesophageal reflux disease and tooth erosion. Int J Dent. 2012;2012:479850.

50. Corrêa MC, Lerco MM, da Cunha Mde L, Henry MA. Salivary parameters and teeth erosions in patients with gastroesophageal reflux disease. Arq Gastroenterol. 2012 Jul-Sep;49(3):214-8.

51. Yoshikawa H, Furuta K, Ueno M, Egawa M, Yoshino A, Kondo S, et al. Oral symptoms including dental erosion in gastroesophageal reflux disease are associated with decreased salivary flow volume and swallowing function. J Gastroenterol. 2012 Apr;47(4):412-20.

52. Gedalia I, Dakuar A, Shapira L, Lewinstein I, Goultschin J, Rahamim E. Enamel softening with Coca-Cola and rehardening with milk or saliva. Am J Dent. 1991 Jun;4(3):120-2.

53. Hanning M. Ultrastructural investigation of pellicle morphogenesis at two different intraoral sites during a 24h period. Clin Oral Invest. 1999 Jun;3(2):88-95.

54. Siqueira WL, Custodio W, McDonald EE. New insights into the composition and functions of the acquired enamel pellicle. J Dent Res. 2012 Dec;91(12):1110-8.

55. Wiegand A, Attin T. Influence of fluoride on the prevention of erosive lesions - a review. Oral Health Prev Dent. 2003;1(4):245-53.

56. Magalhães AC, Wiegand A, Rios D, Buzalaf MA, Lussi A. Fluoride in dental erosion. Monogr Oral Sci. 2011;22:158-70.

57. Lussi A. Dental erosion novel remineralising agents in prevention and repair. Adv Dent Res. 2009;21(1):13-6.

58. Magalhães AC, Kato MT, Rios D, Wiegand A, Attin T, Buzalaf MA. The effect of an experimental $4 \%$ Tif4 varnish compared to $\mathrm{NaF}$ varnishes and $4 \%$ TiF4 solution on dental erosion in vitro. Caries Res. 2008;42(4):269-74.

59. Ganss C, Neutard L, Von Hinckeldey J, Klimek J, Schlueter N. Efficacy of a tin/fluoride rinse: a randomized in situ trial on erosion. J Dent Res. 2010 Nov;89(11):1214-8.
60. Ganss C, Schlueter N, Klimek J. Retention of $\mathrm{KOH}$-soluble fluoride on enamel and dentine under erosive conditions - A comparison of in vitro and in situ results. Arch Oral Biol. 2007 Jan;52(1):9-14.

61. Young A, Thrane PS, Saxegaard E, Jonski G, Rölla G. Effect of stannous fluoride toothpaste on erosion-like lesions: an in vivo study. Eur J Oral Sci. 2006 Jun;114(3):180-3.

62. Huysmans MC, Jager DH, Ruben JL, Unk DE, Klijn CP, Vieira AM. Reduction of erosive wear in situ by stannous fluoride-containing toothpaste. Caries Res. 2011;45(6):518-23.

63. Ganss C, Lussi A, Grunau 0, Klimek J, Schlueter N. Conventiona and anti-erosion fluoride toothpastes: effect on enamel erosion and erosion-abrasion. Caries Res. 2011;45(6):581-9.

64. Levy FM, Magalhães AC, Gomes MF, Comar LP, Rios D, Buzala $M A$. The erosion and abrasion-inhibiting effect of $\mathrm{TiF}(4)$ and $\mathrm{NaF}$ varnishes and solutions on enamel in vitro. Int J Paediatr Dent. 2012 Jan;22(1):11-6.

65. Wiegand A, Waldheim E, Sener B, Magalhães AC, Attin T. Comparison of the effects of TiF4 and NaF solutions at pH 1.2 and 3.5 on enamel erosion in vitro. Caries Res. 2009;43(4):269-77.

66. Hove LH, Holme B, Stenhagen KR, Tveit AB. Protective effect of TiF(4) solutions with different concentrations and $\mathrm{pH}$ on development of erosion-like lesions. Caries Res. 2011;45(1):64-8.

67. Wang X, Megert B, Hellwig E, Neuhaus KW, Lussi A. Preventing erosion with novel agents. J Dent. 2011 Feb;39(2):163-70.

68. Turssi CP, Maeda FA, Messias DC, Neto FC, Serra MC, Galafassi D. Effect of potential remineralizing agents on acid softened enamel. Am J Dent. 2011 Jun;24(3):165-8.

69. Magalhães AC, Wiegand A, Rios D, Hannas A, Attin T, Buzalaf MA. Chlorhexidine and green tea extract reduce dentin erosion and abrasion in situ. J Dent. 2009 Dec;37(12):994-8.

70. Kato MT, Leite AL, Hannas AR, Buzalaf MA. Gels containing MMP inhibitors prevent dental erosion in situ. J Dent Res. 2010 May;89(5):468-72.

71. Kato MT, Leite AL, Hannas AR, Calabria MP, Magalhães AC, Pereira $\mathrm{JC}$, et al. Impact of protease inhibitors on dentin matrix degradation by collagenase. J Dent Res. 2012 Dec;91(12):1119-23.

72. Attin T, Weiss K, Becker K, Buchalla W, Wiegand A. Impact of modified acidic soft drinks on enamel erosion. Oral Dis. 2005 Jan;11(1):7-12.

73. Magalhães AC, Moraes SM, Rios D, Buzalaf MA. Effect of ion supplementation of a commercial soft drink on tooth ename erosion. Food Addit Contam Part A Chem Anal Control Expo Risk Assess. 2009 Feb;26(2):152-6.

74. Beyer M, Reichert J, Heurich E, Jandt KD, Sigusch BW. Pectin, alginate and gum arabic polymers reduce citric acid erosion effects on human enamel. Dent Mater. 2010 Sep;26(9):831-9.

75. Beyer M, Reichert J, Sigusch BW, Watts DC, Jandt KD. Morphology and structure of polymer layers protecting dental enamel against erosion. Dent Mater. 2012 0ct;28(10):1089-97.

76. Johansson A, Johansson AK, Omar R, Carlsson GE. Rehabilitation of the worn dentition. J Oral Rehabil. 2008 Jul;35(7):548-66.

77. Yip HK, Smales RJ, Kaidonis JA. Management of tooth tissue loss from erosion. Quintessence Int. 2002 Jul-Aug;33(7):516-20.

78. O'Sullivan E, Milosevic A. British Society of Paediatric Dentistry. UK National Clinical Guidelines in Paediatric Dentistry: diagnosis, prevention and management of dental erosion. Int J Paediatr Dent. 2008 Nov;18 (Suppl 1):29-38 
79. Azzopardi A, Bartlett DW, Watson TF, Sherriff M. The surface effects of erosion and abrasion on dentine with and without a protective layer. Br Dent J. 2004 Mar 27;196(6):351-4.

80. Reis A, Higashi C, Loguercio AD. Re-anatomization of anterior eroded teeth by stratification with direct composite resin. J Esthet Restor Dent. 2009;21(5):304-16.

81. Attin T, Filli T, Imfeld C, Schmidlin PR. Composite vertical bite reconstructions in eroded dentitions after 5-5 years: a case series. J Oral Rehabil. 2012 Jan;39(1):73-9.

82. Soderholm KJ, Richards ND. Wear resistance of composites: a solved problem? Gen Dent. 1998 May-Jun;46(3):256-63

83. Aliping-McKenzie M, Linden RW, Nicholson JW. The effect of Coca Cola and fruit juices on the surface hardness of glass-ionomers and 'compomers'. J Oral Rehabil. 2004 Nov;31(11):1046-52.
84. Honório HM, Rios D, Francisconi LF, Magalhães AC, Machado MA, Buzalaf MA. Effect of prolonged erosive $\mathrm{pH}$ cycling on different restorative materials. J Oral Rehabil. 2008 Dec;35(12):947-53.

85. Bartlett DW. The role of erosion in tooth wear: aetiology, prevention and management. Int Dent J. 2005;55(4 Suppl 1):277-84.

86. Dahl BL, Krogstad 0. The effect of a partial bite raising splint on the occlusal face height. An x-ray cephalometric study in human adults. Acta Odontol Scand. 1982;40(1):17-24.

87. Hemmings KW, Darbar UR, Vaughan S. Tooth wear treated with direct composite restorations at an increased vertical dimension: results at 30 months. J Prosthet Dent. 2000 Mar;83(3):287-93.

88. Jaeggi T, Grüninger A, Lussi A. Restorative therapy of erosion. Monogr Oral Sci. 2006;20:200-14.

89. Ettinger RL, Qian F. Abutment tooth loss in patients with overdentures. J Am Dent Assoc. 2004 Jun;135(6):739-46.

\section{Livia Picchi Comar}

(Corresponding author)

Al. Octávio Pinheiro Brisolla 9-75,

17012-901. Bauru, SP, Brazil.

Phone/ Fax + 5514 3235-8497

Received: 2013 Feb 15

E-mail: acm@fob.usp.br 